\title{
Making Sense of the Costs and Benefits of Brexit: Challenges for Economists
}

\author{
Iain Begg ${ }^{1}$
}

Published online: 7 August 2017

(C) The Author(s) 2017. This article is an open access publication

\begin{abstract}
The UK's decision to leave the European Union will have a wide-ranging effect on the British economy, but the scale and sequencing of the likely effects are hard to gauge. The uncertainties surrounding how a country separates itself from a regional economic bloc have posed challenges to the economics profession about how best to analyse the many consequences. The paper discusses the main lines of relevant economic argumentation, and reviews the evidence from studies of the likely effects of "Brexit". It then considers how the UK's economic linkages with the EU might evolve and examines some of the ensuing political economy challenges. The concluding section ponders the role of economists in so contentious a political development.
\end{abstract}

Keywords Brexit - UK and European union · Role of economists · Economic integration in Europe $\cdot$ Trade regime $\cdot$ EU finances

JEL $\mathrm{F} 02 \cdot \mathrm{F} 13 \cdot \mathrm{F} 15 \cdot \mathrm{F} 53 \cdot \mathrm{H} 77$

\section{Introduction}

Economic disintegration is a rare phenomenon, and there is scarcely any basis for assessing the separation from a regional economic bloc, such as the European Union (EU), on which the United Kingdom (UK) is about to embark. While conventional tools for analysing pathways towards integration can, by applying them in reverse, provide some insights, disentangling a country from a form of integration as comprehensive as the EU is plainly about much more than rescinding a preferential trading

This article is based on an invited plenary address to the 83rd International Atlantic Economic Society conference, Berlin, 24th March 2017

Iain Begg

iain.begg@1se.ac.uk

1 European Institute, London School of Economics and Political Science, Houghton Street, London, UK 
agreement. Consequently, the secession of the United Kingdom (UK) from the Union poses challenges to economists and the analytical tools of the profession.

These challenges are accentuated by the political ramifications of the Brexit decision and the role in it of expert analysis. During the referendum campaign, those advocating "remain" repeatedly stressed the likely economic costs of leaving the EU, attracting the dismissive label from their opponents of "Project Fear", echoing similar criticisms levelled at the "no" side in the 2014 Scottish independence vote. At one point in the campaign, this even led Michael Gove (one of the dissident members of David Cameron's government allowed to campaign, against the government line, in favor of Brexit) to assert, in a Sky News interview (Gove 2016), "people have had enough of experts".

In the nine months following the referendum, the British economy seemed to weather the storm, growing at around the rate forecast earlier in 2016 on the assumption the country would remain in the EU, triggering predictable gloating from many on the "leave" side. However, growth slowed in the first quarter of 2017 and various survey data, published in the run up to the snap general election called for June 2017, suggested a deceleration of the economy. The unexpected outcome of the general election has accentuated uncertainty, not just about how the UK will now reconfigure its relationship with the EU, and has renewed concerns about the economic impact.

For the economists, as for the pollsters who misread voting intentions in both the referendum and the 2015 and 2017 UK general elections, their credibility as contributors to political debate is under challenge. It can always be argued that public debate is too quick to ignore standard health warnings about margins of error, the need for simplifying assumptions and the fact that projections are often "what if" exercises. Equally, the use (and misuse) of the various modelling exercises has often been predicated on an exaggerated certainty about the quality and robustness of analysis, suggesting that the involvement of economists in contentious political issues is fraught with danger. The resulting conundrum is how to reconcile making effective contributions to debates in which economics ought to have a contribution to make, while retaining enough detachment to be (and be seen to be) non-partisan. This article continues by summarising some of the key views about how leaving the EU will affect the UK economy, then turns to ex-ante assessments of the likely impact on the UK economy. The following sections discuss the UK's trade linkages and the political economy of Brexit. A concluding discussion examines the implications for economists.

\section{Conflicting Academic Views}

Although the evidence (Crafts 2016) suggests UK economic performance, loosely defined, benefitted from EU membership, it need not follow that being outside the EU will cause a reversion to harmful old ways. Crafts points to the pro-competitive effects of membership, accentuated by being within the single market, and their incidence on productivity. Recently, however, UK productivity growth (in common with many other major economies) has been lacklustre, raising the issue of whether the EU effect was fading. Certainly, since joining the EU in 1973, the UK's exports have changed substantially, with exportable services accounting for an increasing share.

Prior to the June 2016 referendum, many attempts were made to model the likely impact of Brexit, including from various official bodies (such as the International 
Monetary Fund [IMF], the Organization for Economic Cooperation and Development [OECD], Her Majesty's [HM] Treasury and the Bank of England) and from independent researchers. The principal work-horse of these exercises was the gravity model (for example, HM Treasury 2016a; Ebell and Warren 2016; CEP 2016) with its simple intuition that trade and other economic linkages will be most intensive with geographically proximate partners. There are, as might be expected, differences of methodology, emphasis and assumptions among these studies, but they can be considered to represent the mainstream.

An opposing view is articulated by Minford (2016a, p. 4) who maintains that gravity models, despite the evidence that they "predict the levels of trade well in a statistical sense [can only be relied upon] as long as the basic assumption that everything else is held constant is true (i.e., all the shocks and fixed assumptions implicit in the underlying empirical analysis, such as other tariff and policy changes and technological developments"). His alternative is a rational expectations model, with its central assumption that economic agents will respond to as significant a regime change as leaving the EU by adapting their behaviour. He goes on to argue that when there is a wide-ranging change not only in the trade regime, but also in the nature of regulation, the statistical regularities on which the gravity models depend, cease to be reliable - in short, a Lucas critique argumentation. By implication a small change in, say, a tariff (such as reducing it from $10 \%$ to $8 \%$ ) can be analysed using gravity models, but a wholesale change in the regime cannot.

Minford's optimistic assessment of Brexit relies substantially on the theoretical proposition that unshackling the UK from the EU would have strong trade-creating effects and negligible diversion. It further assumes that unilateral abolition of trade restrictions by a post-Brexit UK would be the best strategy because British consumers would, at a stroke, benefit from an improved standard of living as a result of lower prices. In parallel, UK businesses would have their competitiveness boosted through no longer having to comply with onerous (and costly) regulations.

Minford and Miller (2017) advocate unilateral reduction of trade protection because it would benefit consumers who might then be more willing to countenance structural reforms designed to boost productivity. They also maintain that the short-term uncertainty around Brexit can be minimised by moving rapidly to eliminate protection, not least because there would be nothing of substance to negotiate. Lower import prices (presumably because they are, in part, inputs to other industries) would stimulate "the expansion of the unprotected service sector". Even so, they do not explain how this will enable Britain, already with a large deficit on the current account of the balance of payments, to pay its way in the world, especially in light of their stated view that this policy would see much of manufacturing being lost.

In a hard-hitting rebuttal of the Minford critique, the Centre for Economic Performance (CEP) (2016, p. 88) observes that "to take the position that since no econometric work can be perfect, all inconvenient facts should be ignored is poor scholarship and bad science". They assert that the argumentation by Minford is flawed because it relies only on theoretical propositions of dubious merit. As well as highlighting the lack of empirical evidence, they question the view that there is significant trade diversion and cast doubt on the proposition that consumers are concerned only with the lowest price such that once they escape from EU protection they will switch from EU producers to lower cost third country producers. This might have some effect if what was being 
purchased was an identical commodity (think of a barrel of oil or a metric ton of grain), but most purchases these days are of goods (and services) which have distinctive characteristics depending on where they come from: a basic Tata car is only a partial substitute for a basic BMW, let alone a top of the range one.

An obvious question is whether these are arcane academic disputes in which there is no right or wrong, only competing standpoints, or whether one side should be accorded much more credibility than the other. A basis for an answer is the weight of theoretical and empirical support for the approaches adopted by the leading contributors, although Bootle (2017) sees this as a problem in itself, implying a form of "group-think".

\section{Ex-Ante Assessments}

Research undertaken in advance of the referendum on how the UK economy would be affected by a decision to leave the EU was of three distinct types: macroeconomic forecasts; projections of the short-term consequences based on scenarios; and longerterm analyses of different likely outcomes. Forecasters generally agreed that a "leave" vote would have a negative effect on the economy. Similarly, those engaging in scenario exercises projected adverse short-term shocks. Most of the third group of studies reached two main conclusions. First, leaving the EU would result in a loss of gross domestic product (GDP) (relative to what would otherwise be attained, not necessarily in absolute terms) over a 15-year horizon, compared with remaining in the bloc. Second, the scale of the loss would depend on the extent of the post-Brexit barriers to trade and investment exchanges between the UK and the rest of the EU (rEU).

\section{Short-Term Effects: A Forecaster's Nightmare?}

Short-term forecasting has had a difficult time with Brexit. There was a consensus that the immediate effects of a "leave" vote would lead to a slowdown, yet on the basis of the data for the four quarters following the vote, it is hard to detect any real deviation from trend. Examination of some of the leading official forecasts shows the havoc this has played with projections. Thus, in successive quarterly forecasts for 2017 and 2018, the Bank of England shifted from a sharp slowdown in 2017 to a trajectory in line with what had been forecast before the referendum result. For 2018, the forecasts have been more stable. The Bank of England's most recent forecast has again projected a slowing of the UK economy in 2018

Table 1 GDP forecasts for 2017-2019

\begin{tabular}{|c|c|c|c|c|c|}
\hline \multirow[b]{2}{*}{$\begin{array}{l}\text { For } \\
\text { year }\end{array}$} & \multicolumn{5}{|c|}{ Forecast from } \\
\hline & $\begin{array}{l}\text { May } \\
2016\end{array}$ & $\begin{array}{l}\text { August } \\
2016\end{array}$ & $\begin{array}{l}\text { November } \\
2016\end{array}$ & $\begin{array}{l}\text { February } \\
2017\end{array}$ & $\begin{array}{l}\text { May } \\
2017\end{array}$ \\
\hline 2017 & 2.3 & 0.9 & 1.4 & 2.0 & 1.9 \\
\hline 2018 & 2.3 & 1.8 & 1.5 & 1.6 & 1.7 \\
\hline 2019 & & & 1.6 & 1.7 & 1.8 \\
\hline
\end{tabular}

Source: Monthly Bank of England Inflation Reports (May 2016-May 2017) 
and 2019. "Forward guidance" following the start of the negotiations, immediately after the indecisive general election of June 2017, signalled no early rise in interest rates (Table 1).

These findings are consistent with what many other forecasters have said and are not singled out for criticism, as such. On the contrary, they serve to illustrate the underlying problem of generating worthwhile projections in a period of such profound uncertainty (ambiguity) about what is happening. But in political economy terms, the lack of clarity is a cause for concern, because it had (or had the potential to have) marked effects on the political discourse and the policy choices being made.

\section{Short-Term Projected Effects of Brexit}

For the short-term, perhaps the most widely quoted scenario analysis was undertaken by HM Treasury (2016b) in an exercise completed just one month prior to the referendum. It modelled Brexit as two possible shocks to the economy: "shock" and "severe shock", in both of which the economy is hit by three main effects. These are:

- The direct "transition effect" of shifting to less open trade and investment regimes. Employers reliant on the current trade regime would be faced with pressures to reduce costs and would be expected to reduce investment.

- Uncertainty arising from not knowing how the negotiations would unfold, also affecting key economic decisions, notably investment.

- A financial stability effect resulting from a reassessment by financial markets of the riskiness of UK assets.

According to the Treasury (2016b, p. 5), the short-term effects of Brexit, even in their least adverse scenario:

"would cause an immediate and profound economic shock creating instability and uncertainty which would be compounded by the complex and interdependent negotiations that would follow. The central conclusion of the analysis is that the effect of this profound shock would be to push the UK into recession and lead to a sharp rise in unemployment".

The Treasury analysis is peppered with the adjectives "immediate" and "profound", although it was predicated on a rapid triggering of Article 50 (the provision in the EU Treaty for a country to exit, requiring a member formally to give notice of its intention to leave) and focused on the two-year period during which the UK's exit from the EU would take place. In the study, this meant from the third quarter of 2016 to the middle of 2018. The triggering of Article 50 was, however, delayed by nine months until the end of March 2017, and the subsequent decision by Theresa May to call a snap general election added to the delay.

The Treasury "shock" scenario was expected to result not only in a loss of $3.6 \%$ in GDP over two years, compared with what would otherwise happen (potentially a mild recession given the growth rate previously expected in the two years from the end of Q2 2016) and a jump in unemployment, but also 


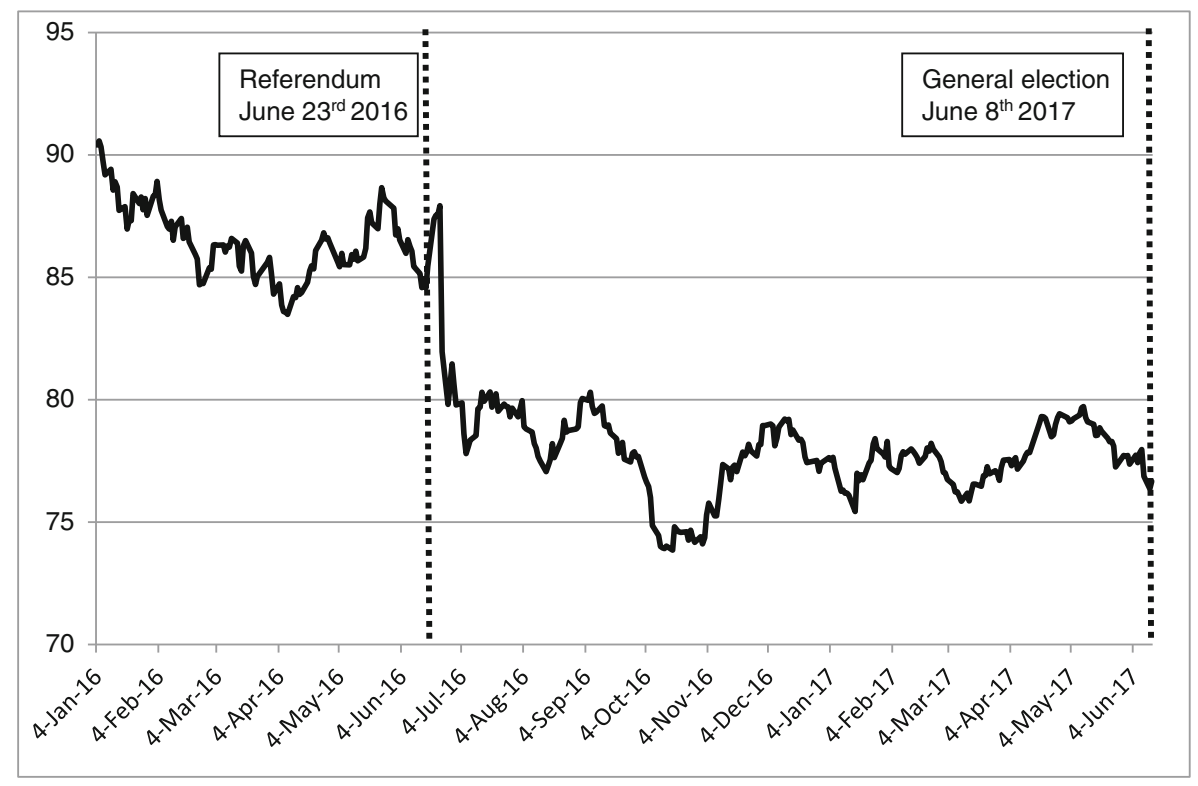

Fig. 1 UK Real effective exchange rate, $2005=100$. Source: Bank of England (2017)

higher inflation because of a fall in the pound. Under the severe shock scenario, GDP would have been some $6 \%$ lower after two years and the unemployment and inflation effects would be greater. Moreover, the Treasury did not allow for what it calls "tipping-points", such as a sudden stop in the willingness of financial markets to finance the already large UK deficit on the current account of the balance of payments.

It would be disingenuous to argue that Brexit did not impinge on the economy in these initial months. There was some financial instability, visible at least in the foreign exchange market and the stock market, although nothing as dramatic as a run on a bank or a credit crunch. By the third quarter of 2016, the real effective exchange rate of the pound was some $15 \%$ lower than at the start of the year (Fig. 1). By contrast, the FTSE 100 index surged, partly reflecting the windfall gains in sterling to profits from other parts of the world: indeed, financial markets became accustomed to the two moving inversely. The delay in triggering Article 50 and the impression of disarray in government on the negotiating stance have, if anything, added to the uncertainty. The "transition" effect may not yet have started, but it would be hard to argue that the other two were absent.

\section{Explaining the Apparent Resilience of the Economy}

Does the subsequent resilience of the economy imply the Brexit decision has had no economic impact and the Treasury, simply, was wrong in its conclusions about the immediate impact, casting doubt also on what it said about the longer term? Again, the conclusion would be disingenuous. Could it be that the Treasury's reasoning was correct, but the timing awry? There is support of sorts for this proposition from Andy 
Haldane, Chief Economist of the Bank of England, speaking at the Institute for Government (2017):

"I think, near-term, the data, the evidence we've been accumulating since the referendum, has surprised to the upside. [There's been] greater resilience, in particular among consumers and among the housing market, than we had expected. Has that led us to fundamentally change our view on the fortunes of the economy looking forward over the next several years? Not really. This is more a question, I think, of timing than of a fundamental reassessment of the fortunes of the economy."

The devaluation of the pound is one plausible explanation for the resilience shown by the economy, yet in a way that belies standard analysis positing an immediate, adverse terms-of-trade effect, eroding real incomes, but only later a favourable effect on growth through expenditure switching. Although, as Fig. 1 shows, the effective exchange rate fell sharply as a result of the referendum decision, it took several months for inflation to start creeping upwards. Consumer expenditures and the large service sector kept the economy buoyant, and casual observation of tourism data suggests there was an immediate boost from tourism, with more nights and higher per-tourist spending in the UK over the summer of 2016 compared with the two previous years. The decline in the exchange rate was correctly foreseen by the Treasury, but its model appears not to have captured the sequencing of its effects on the economy.

The rapid anointment of Theresa May as the successor to David Cameron, arguably, helped by forestalling a divisive leadership campaign and avoiding the political uncertainty which she then, ironically, brought on herself by calling a general election. Policy responses have also helped. In August 2016, an already loose monetary policy was loosened slightly further and the incoming chancellor signaled a slight relaxation of fiscal policy. Neither change was of great quantitative import, but the message of willingness to respond manifestly had a calming effect on economic actors and markets.

\section{Longer Term}

Assessing what will happen 10 or 15 years hence as a result of a change as significant as leaving the EU requires careful specification of the counterfactual, alongside more extensive simplifying assumptions. Consequently, deriving the counterfactual from past experience is likely to be harder than is customary when more limited changes are being analysed. If the long-run trend is for the economy to grow at, say, 2\% per annum, then it is reasonable to use a projection of continued growth at that rate for the foreseeable future, while building in some uncertainties.

A typical example of longer-term scenarios was the assessment by HM Treasury (2016a) of a range of scenarios. These comprised leaving the EU, but retaining full access to the EU single market and thus having a future relationship with the EU similar to Norway; negotiating a comprehensive free trade deal with the EU, along the lines of the one recently concluded by Canada; or shifting to standard World Trade Organisation (WTO) rules. The outcomes for GDP and jobs, as projected by HM Treasury (echoed in work by others), were that the Norway model would be least damaging, the Canadian model more so, but less than the WTO model. 
Among those contributing to the analyses, the range of estimates is large, from a loss of GDP of nearly ten percentage points (in the least attractive trade and inward investment scenarios modelled by HM Treasury (2016a; Ebell and Warren 2016; and CEP 2016) to the gain of four points estimated by Minford et al. (2016), a clear outlier. In general, the scenarios least damaging to the UK interest are those that involve the fewest restrictions on the UK's future access to the rEU, whereas those that result in new barriers to UK trade or inward investment are the most damaging. However, the range of policy areas in which change will be required is daunting, as even the brief overviews of the challenges in Baldwin (2016) show.

\section{Who Needs the UK and who Does the UK Need?}

The choices the UK faces on both trade and the approach to regulation of the economy afford opportunities for tailor-made solutions, but also carry the risk that desirable options will be unattainable. The UK aspiration to retain market access while limiting immigration is unlikely to be attainable for two reasons: first, because it will be seen as trying to have its cake and eating it; and second, it would be expected to provoke similar demands from others. Member States all have their own priorities for the single market and could be expected to oppose (or even veto) proposals giving concessions to the UK without offsetting benefits for themselves. Much will depend in this and other respects on the distinction between transition effects and permanent effects. The former will, more often than not, be damaging to economic performance, especially if they accentuate uncertainty.

After completing the Article 50 "divorce" process, but while awaiting a new trade deal with the likes of the US or China, for example, the UK will be less able to specialise in those activities for which it is most suited. Asymmetry of bargaining power is also germane. A rather cavalier perspective among pro-Brexit campaigners was that free from the need to achieve consensus among all 28 members of the EU, the UK would be able to move rapidly to conclude new trade deals, with the success of Switzerland in securing a trade deal with China in 2013 cited in evidence, something that has eluded the EU. Yet, according to Evenett (2016) it is a very one-sided deal given the Chinese reluctance to offer concessions on key areas. The counter-argument is that the UK, as a much bigger economy, has the clout to achieve more balanced deals, but this cannot be taken for granted and may fall well short of the still greater clout of the EU.

In addition, the timing of change has to be taken into account. The UK could achieve more attractive trade arrangements with counter-parties outside the EU, but only after a protracted negotiation during which it is likely to be at a disadvantage compared with present arrangements. Moreover, the arithmetic of trade will matter. As Fig. 2 shows, the U.S. is the UK's biggest single export market, but reliance on EU markets is substantial. UK exports in 2016 to India were lower than to Poland, and even a doubling of exports to what is now the world's most populous country would still only mean $2 \%$ of UK exports. Similar reasoning applies to other Commonwealth countries. 


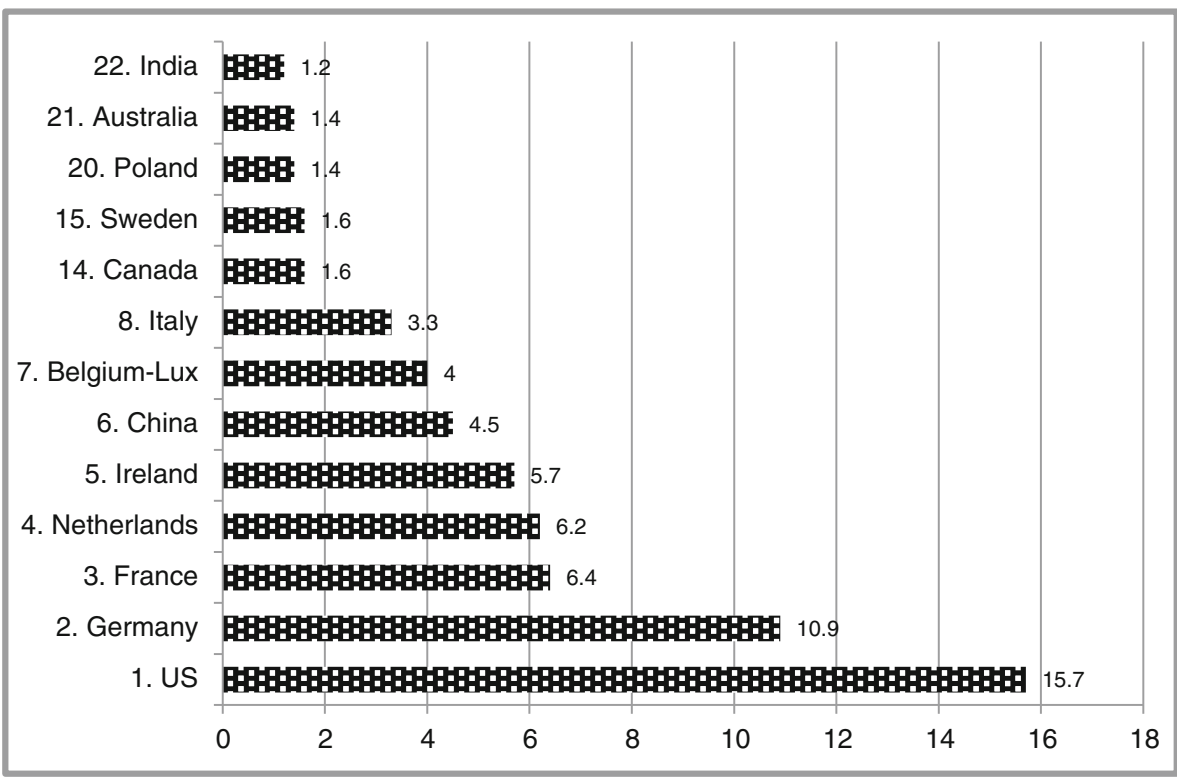

Fig. 2 Shares of UK exports going to a selection of its largest markets, \% of total exports (2016). Source: UK Office for National Statistics (2017)

Sampson (2017) suggests four principles to guide the UK's negotiating strategy. It is instructive, drawing on his framework, to assess where the UK stands in relation to them. The principles are:

- You get what you give because a successful negotiation requires concessions on both sides in the interests of achieving a mutually beneficial deal. The UK has acknowledged that its "red lines" on curbing intra-EU migration are incompatible with continued membership of the single market, but its stance on the customs union is more contentious. Some on the UK side have argued for unilateral tariff reductions (e.g., Minford 2016), justified by the benefits to consumers of lower prices, but Sampson maintains that signalling such a preference would give away a bargaining chip prematurely.

- Where negotiations start matters. Sampson stresses that part of this criterion is having a credible fall-back position should the negotiations fail - what he calls a "threat" point, typically the status quo. What is distinctive about Brexit is, unless the UK body politic does what seems out of the question by reversing the decision to leave the EU, the fall-back position is itself an unknown. There have certainly been voices on the UK side, including David Davis (currently leading the negotiations on the UK side), initially prepared to envisage a breakdown rather than a bad deal. The implication is that the UK would become a third country, in standard WTO terms, in relation to the EU, but the UK manifestly lacks a clear understanding of what this means, including for existing EU agreements with other countries to which the UK is currently a party.

- Bargain from a position of power. For Sampson, the UK is vulnerable because it needs a deal much more than the rest of the EU. A standard retort has been to point to 


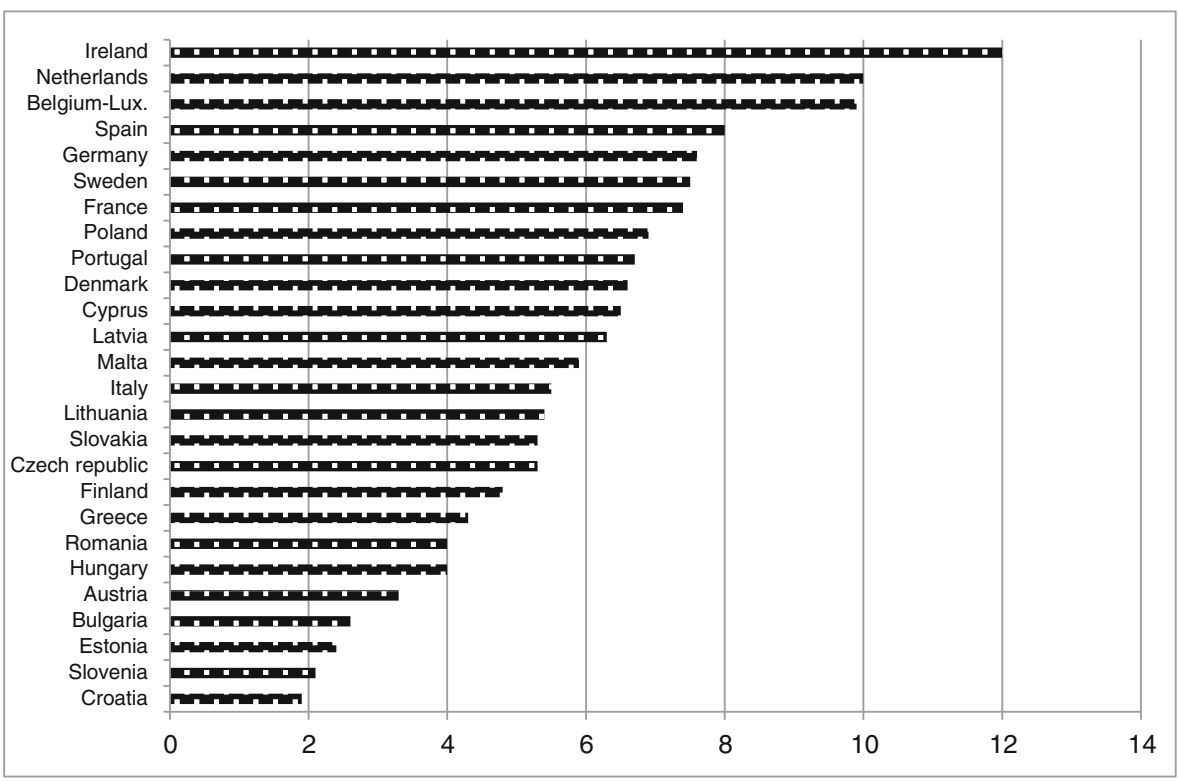

Fig. 3 Share of other EU member states' export going to UK, 2015, \%. Source: Observatory of Economic Complexity (2017)

the importance of the UK market for leading exporters, with the corollary that the CEO of the likes of BMW would be straight on the phone to the German Chancellor if there was a threat of obstacles to its market access. The data in Fig. 3 point to an additional dimension of the power balance, namely the differing degree of dependence on the UK market of the other Member States of the EU, with two ramifications. First, there will indeed be Member States, including powerful ones such as France, Germany and Spain (all exporting enough to the UK for it to matter) with strong incentives to reach an accommodation with the UK. Their weight in the collective EU deliberations will be influential. Second, however, smaller Member States, such as those in central, eastern and southeast Europe are much less connected to the UK, and may be in a position to exercise a veto. Slovenia, for example, exports 10 times as much to Germany as to the UK, with the latter only taking $2 \%$. The potential for a veto rests in part on a rather obscure aspect of EU law, namely whether a deal with the UK is regarded as exclusively for the EU level to negotiate, or a mixed agreement for which approval is required from the 27 other Member States and some sub-national parliaments (as with the recently concluded Canada EU deal, when the Wallon region in Belgium initially blocked a deal).

- Invest in negotiating capacity may seem obvious, but has to be seen in the context of 44 years of UK membership in the EU with competence for trade policy formally assigned to the supranational level. Notwithstanding the UK civil service's reputation for adaptability, the sheer lack of critical mass in the minutiae of trade deals calls for a combination of rapid recruitment, from a shallow skills pool, of the required specialists, together with learning-by-doing. It carries the evident risks of being out-manoeuvred by a seasoned opponent or taking far longer than hoped. The latter risk would imply a transitional period of uncertain duration. 
The UK economy is increasingly dominated by private services, including in its mix of exports. As Fig. 4 shows, the automobile industry - once a byword for all that was wrong in UK manufacturing, but now very much dominated by inward investors highly competitive in global markets, such as Nissan, Toyota and BMW - is now a success in exporting, much of it depending on demand from EU partners. Half the production of Nissan UK is exported to EU countries. Even so, imports of automobiles continue to exceed exports. By contrast, UK exports of business services and of financial services are both substantial and in net surplus. In the Brexit context, they give rise to distinct concerns because, in contrast to trade in goods for which tariffs and other conventional barriers (already low after successive global trade rounds) are the issue, trade in services is affected predominantly by regulatory "behind-the-border" barriers. Even those who believe it should be possible to achieve a trade deal rapidly with the rEU acknowledge that services will be trickier, not least because the UK surplus in these industries is a disincentive to rEU to be too accommodating in these sectors.

An aspect prone to be given too little prominence is that international trade these days is increasingly dominated by value chains in which, unlike more traditional conceptions of specialisation in final goods or services, countries tend to specialise in stages in the production process (Baldwin 2012). These stages of production include design, marketing, production of specialised components or software and so on, as well as assembly. Because such activities require close planning and integration of different stages of the production process, any obstacles to easy movement across borders could have a negative effect on the UK's competitiveness as a location in which to invest. Any new frontier restrictions, such as the re-imposition of customs barriers, could lead to fragmentation of supply-chains established across the EU in many industries. This effect will be separate from formal trade restrictions, but as the research carried out in assessing the "costs of non-Europe" (summarised in Cecchini 1988) showed, there are sizeable costs associated with market fragmentation.

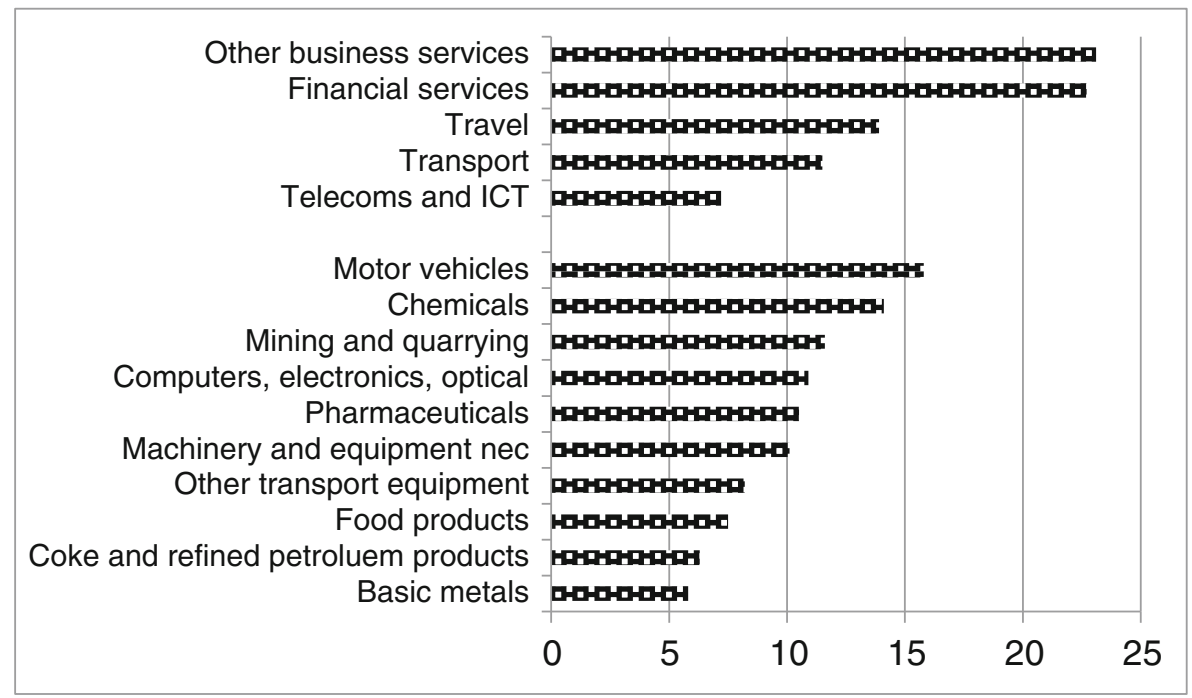

Fig. 4 The UK's largest export industries, 2015, value of exports, £ billions. Source: HM Government (2017) charts 8.3 and 8.4 , based on ONS data 


\section{Political Economy of Brexit}

Despite the general message from economic analyses that Brexit will be damaging to the UK economy, there is by no means a consensus on the extent of the loss or of the crucial determining factors. Yet by the time hard evidence is available, it will be too late because whatever form a new deal with the UK takes will long since have been concluded. As with any major change in the economic environment, Brexit is bound to create winners and losers. Making sense of the referendum outcome has not been easy, bearing in mind that voters knew on the whole, what they were voting against (either leaving or stayingin the EU), but had much less idea of what they were voting for, especially on the leave side. The distinct electoral cleavages revealed in the referendum voting patterns point to interests that might be expected to win or lose from leaving the EU.

Becker et al. (2017), in a fascinating analysis at a highly disaggregated geographical level of who voted which way, find that public service provision was telling, reinforcing what they refer to as weak fundamentals of low wages, lack of skills and a reliance on manufacturing industries in decline. Their findings on immigration are more nuanced: there is a weak link between a "leave" vote and the growth in migrants from the countries which joined the EU in 2004 and 2007, a sizeable proportion of which are from Poland, but not with migrants from the 14 other pre-2004 EU member states or from the rest of the world. However, comparatively little attention has been paid in empirical work to the likely distributive effects of Brexit, leaving the matter vulnerable to accusations unsubstantiated by evidence that, for example, EU migrants held down the wages of indigenous workers or that the EU is only advantageous for elites.

\section{Trade Regime}

Any change in a trade regime will lead to a range of standard effects, although until the contours of new trade deals become known, likely magnitudes cannot readily be estimated. In relation to the EU, the UK will move from being a full member of the single market to something short of this status. It was conceivable, even likely, prior to the "snap" general election, that it would cease to be part of the EU customs union because leaving would allow the UK the freedom to conclude new trade deals with other global partners. This will give rise to a range of trade creating and trade diverting effects. Trade creation from liberalisation of trade with non-EU countries would be accompanied by diversion of trade from EU suppliers on the assumption of the erection of new barriers.

As an economy in which private services account for a steadily increasing share of GDP (manufacturing is now barely 10\%), the UK is particularly affected by the distinctive obstacles facing transport, financial and business services in accessing markets in other countries. For the City of London, a major concern is the prospect of segments of business being lured, whether for commercial or regulatory reasons, to other countries. In this regard, other financial centres in Europe are only part of the story because the rationale for businesses from the rest of the world choosing London as a location from which to serve both European and global markets could be undermined. London, as a financial centre, has major attributes and will remain a leading player, but the indications are that some activity will depart. If the relocation is across the Atlantic rather than across the English Channel, as seems not 
improbable, it would have an adverse effect on both the UK and rEU and, as some wiser heads on the continent recognise, be damaging for the provision of financial services across the EU. Negotiators are slowly becoming aware of this lose-lose risk.

\section{Labour Market}

Such evidence as there is on the wage effect finds it to be negligible or non-existent (summarised in CEP 2016). The same report, examining the likely effects of Brexit on the prices of consumer goods and services, finds that all income deciles and social groups (such as pensioners or lone-parents) will be negatively affected. There are minor differences, with marginally the heaviest costs borne by those in the middle of the income distribution, while those in the lowest decile are affected least.

Turning to likely outcomes, some broad inferences can be drawn. If, as expected, there is a reduction in the number of EU citizens working in the UK, both their incomes and the remittances they send to their home countries will diminish. Whether this favours indigenous UK citizens will depend on the degree to which they can push up wage rates and, effectively, substitute for the displaced workers. New migrants often compete most directly with previous immigrants and less so with indigenous workers, leading to the somewhat ironic implication that a curb on new migrants will benefit "old" migrants more than those who voted for Brexit (Petrongolo 2016).

\section{Public Finances}

How Brexit affects the UK's public finances will be the result of the interplay between a range of determinants. As a net contributor to the EU budget, the UK would have direct savings from ending its payment to Brussels. There will also be indirect effects, primarily depending on how Brexit affects economic performance. In evidence to the House of Commons Treasury Committee late in 2016, Robert Chote (who heads the UK's independent fiscal watchdog, the Office for Budget Responsibility) suggested that the forecast slowdown in the economy would lead to a $£ 12$ billion per annum worsening of the UK fiscal deficit - more than the net saving from ending UK payments to Brussels. There is a related concern that if profitable financial services companies exit the UK, there will be a disproportionate fall-off in corporate tax revenue, similar to what occurred during the financial crisis. There may also be lesser costs associated with, for example, enhanced border controls.

Claims and counter-claims about the EU budget and how much the UK contributes towards it abounded, both before and after the referendum, many of them downright misleading. Among the most egregious during the campaign was the statement that the UK "sends $£ 350$ million per week to Brussels", usually leading to the assertion that Brexit would liberate the same amount to be spent on the National Health Service (NHS). Analysis by the House of Commons Treasury Committee, a public statement by the UK Statistics Authority (2016), as well as academic work by Begg (2016), all show that the figure is, quite simply wrong. There are differing ways of estimating the figures, but the true amount is between $0.3 \%$ and $0.7 \%$ of GDP, depending on whether a gross payment or one net of EU money spent in the UK is used. Even under the most generous interpretation, the amount was at most $£ 280$ million per week. This is substantial, yet it was striking 
during the campaign how successful the "leave' side" was in planting the exaggerated amount in public discourse.

Subsequently, the issue of the UK paying a Brexit "divorce bill" emerged as one of the costs of Brexit, unsurprisingly, raising hackles in the UK. The figures now being discussed, as high as $€ 100$ billion, representing more than five times the current gross annual payment from the UK and of the order of $3 \%$ of UK GDP, are proving to be very poisonous to the negotiations, although at the time of writing an early settlement on a more moderate amount seems likely.

\section{Cost of EU Regulations}

Regular claims, some of rather dubious provenance, were made about the burden on UK businesses from excessive regulation emanating from Brussels. These too have been contentious because of a propensity to confuse direct compliance costs, the possible counter-factual of either being liberated from EU rules or having better tailored national rules, and the widespread neglect of the potential benefits of regulation. Rather than engage in a well-conceptualised analysis of the costs and benefits, even prominent economists have resorted to concocting a headline figure and asserting it as a cost.

In a critical report, the House of Commons Treasury Committee (2016: para 61) is especially trenchant:

" $£ 33.3 \mathrm{bn}$, or $£ 600 \mathrm{~m}$ per week, is an estimate of the total cost to firms of complying with the top 100 most 'burdensom' EU regulations. It is not the net economic cost of regulation, nor is it a measure of the savings that would accrue to businesses as a result of Brexit. To assert this is misleading. To persist with such a claim, as both Vote Leave and Leave.eu have done, is a tendentious representation of the research on which it is based."

Indeed, a bonfire of regulations is put forward in some quantitative analyses (Minford et al. 2016) as one of the principal means by which the UK economy will gain from being outside the EU. It is interesting to note that in early skirmishes in the Brexit negotiations, the May government had made implicit threats to shift to a low regulations model of capitalism if the rEU side did not offer sufficiently attractive terms for a post-Brexit economic relationship. This, in turn, nourished the narrative of "no deal is better than a bad deal" from Theresa May and her most pro-Brexit ministers. Since her comeuppance at the hands of the votes in the June 2017 general election, this line of argumentation, always dubious, has faded from view. Administrative costs for importers and exporters, associated with the re-imposition of border checks, are likely to arise if the UK does not remain in the customs union.

\section{Role of Economists}

Doubts about the pro-market, pro-globalisation economic models, dominant in recent decades and central to institutional structures in the advanced capitalist economies, have surfaced in many forms in recent years. It can be argued that economic reasoning has been highly influential in the drive to establish and 
shape entities such as the European Union, even though political rationales have always been prominent.

The challenge for the economics profession is not only to generate appropriate economic analysis, but how to intervene in public debates of this sort. On both counts, Brexit has been revealing and, even if the parallels are prone to exaggeration, the appeal of Trump, the Cinque Stelle (Five Star) Movement in Italy or populists in other European countries pose questions about how messages from economists are interpreted and used.

Study after study showed, for example, that EU nationals working in the UK boost GDP, make a positive contribution to the public finances and are vital to labour supply, including in sectors such as health care, a highly valued sector in public opinion. Why, then, was immigration so toxic an issue in the referendum?

An intuitive explanation can be characterised as the "tyranny of the average". Relevant macroeconomic aggregates may indeed increase, but pointing to something which increases an average, such as GDP per head or the employment rate across the economy, is not the same as a gain to the individual citizen, household or locality. When there is a disjunction between where or to whom gains and losses accrue, it goes beyond what can be thought of as misguided perceptions. To the indigenous resident facing competition from a migrant worker for social housing or for a school place for a child, it is a reality.

What all this means for the form of Brexit is in flux, particularly after Theresa May's decision to call a "snap" general election backfired so spectacularly. The EU side is adamant that membership of the single market requires the "four freedoms", of movement of goods, services, capital and labour, to remain inviolable. British insistence on curbing flows of EU migrants logically means exiting the single market, implying the option (the Norway model), shown in most studies to be the least costly, cannot apply. Prior to the general election, this was UK government policy (generally referred to as hard Brexit), set out in a White Paper (HM Government 2017). After the election, the tone shifted toward seeking a softer form of Brexit, with the hitherto muted business community becoming more vocal, but unless the insistence on migration curbs is either abandoned or watereddown to a degree acceptable to the rEU (unlikely) it will be a case of either/or.

In the UK context, the weak state of the public finances, still on a (slow) recovery path from the large deficits posted at the height of the financial crisis, became a consideration. The solid empirical evidence from Dustmann and Frattini (2014) showed how migrants made a net contribution to public finances which is not that surprising because they tend to be young, often single and childless, and have a high employment rate. The additional tax generated by the influx of EU workers could have been used to expand public service provision, but the need for fiscal consolidation militated against this. This led to something of a paradox. In per capita terms, public services were being squeezed and it became easy to blame migrant workers despite their net contribution to public coffers.

During the 2016 EU referendum campaign, UK voters were assailed by studies and projections offering conflicting analyses, making it difficult for them to judge who was likely to be broadly right, who engaged in sloppy research or made implausible assumptions and who was doing little more than making unwarranted assertions. The essence of the economic narrative around Brexit was that it will result in losses for the UK, with the obvious corollary that citizens are inflicting harm on themselves if they vote for it. In short, it is the (political) economy. 
To sum up, Brexit posed three distinct challenges to the economics profession and it remains unclear how convincingly they have been met. The first is whether the techniques adopted were appropriate. Here, the jury will be out for some time because the bulk of the work undertaken was about long-run scenarios. The "experiment" is in progress, but it will be a decade or more before sufficient empirical data become available to evaluate it. The short-term resilience of the UK economy has, at first sight, contradicted the generally pessimistic ex-ante analyses, but there is a credible retort that the effects may just have been postponed rather than incorrectly modelled, although the magnitudes of, for example, the Treasury (2016b) "severe shock" scenario do now look wildly askew.

Second, the economics profession has to reflect on how it participates in such politically-charged debates. Precisely because it is a social science, economics cannot produce certainties. How analytic findings are used by partisan politicians cannot easily be controlled, but at what point and to what extent do economists have a responsibility to contradict misuse of their findings? In the UK referendum on EU membership, the clear public message from economists was of loss from Brexit and it was, on the whole, presented with confidence and certainty. In Scotland, the tactic of scaring the voters worked in 2014 but in the EU decision it did not. Indeed, Aaron Banks, a prominent Brexit supporter who contributed a large amount of funding to the effort, was widely quoted for his view that any economic loss "would be a price worth paying".

The third challenge is in many ways the trickiest. Assuming and, in the light of the outcome of the June 2017 general election, nothing can be taken for granted, Brexit proceeds along the lines mapped out by the May government and results in departure from the European single market, the UK will have to transform its economic model in a variety of ways. It will also have to rethink, and possibly replace, a variety of policies for which, up to now, there has been complete delegation to the EU level or the latter has exerted a strong influence on UK approaches. Whether for industrial policy, regional policy or a vast swathe of regulatory interventions, a fresh start will be needed. Can economists tainted by accusations of having connived in project fear make their voices heard?

Open Access This article is distributed under the terms of the Creative Commons Attribution 4.0 International License (http://creativecommons.org/licenses/by/4.0/), which permits unrestricted use, distribution, and reproduction in any medium, provided you give appropriate credit to the original author(s) and the source, provide a link to the Creative Commons license, and indicate if changes were made.

\section{References}

Baldwin, R. (2012) 'Global value chains: Why they emerged, why they matter and where they are going' CEPR Discussion Paper no. 9103, London: CEPR, http://cepr.org/active/publications/discussion_ papers/dp.php?dpno=9103.

Baldwin, R. (Ed.). (2016). Brexit beckons: Thinking ahead by leading economics. London: CEPR.

Bank of England (May 2016-May 2017). Inflation reports, http://www.bankofengland.co. uk/publications/Pages/inflationreport/2016/aug.aspx.

Bank of England (2017). Statistical interactive database - interest \& exchange rates data, http:/www. bankofengland.co.uk/boeapps/iadb/index.asp?Travel=NIxIRx\&levels $=1 \& X N o t e s=Y \& X N o t e s 2=$ Y\&Nodes $=$ X3790X33940X3951\&SectionRequired=I\&HideNums=-1\&ExtraInfo=true\&A41107 XNode3951.x=3\&A41107XNode3951.y=5. 
Becker, S.O., Fetzer, T., \& Novy, D. (2017) 'Who voted for Brexit? A comprehensive district-level analysis', CESifo Working Paper no. 6438, http://www.cesifo-group.de/ifoHome/publications/workingpapers/CESifoWP/Featured-CESifo-Working-Papers/2017/CESifoWP6438_Feature.html?eNLces-201704.

Begg, I. (2016). The EU budget and UK contribution. National Institute Economic Review, No.236, 39-49.

Bootle, R. (2017). The Trouble with Europe: How to Make a Success of Brexit and Reform the EU 4th edition. London: Hodder and Stoughton.

Cecchini, P. (1988) The European challenge, 1992: The benefits of a single market, Aldershot: Gower.

CEP. (2016). Brexit 2016: Policy analysis from the Centre for economic performance. London: Centre for Economic Performance http://cep.lse.ac.uk/BREXIT/abstract.asp?index=5104.

Crafts, N. (2016) 'The growth effects of EU membership for the UK: A review of the evidence', University of Warwick CAGE Working Paper no. 280, http://www.smf.co.uk/wp-content/uploads/2016/04/SMFCAGE-The-Growth-Effects-of-EU-Membership-for-the-UK-a-Review-of-the-Evidence-pdf.

Dustmann, C., \& Frattini, T. (2014). The fiscal effects of immigration to the UK. Economic Journal, 124, F593-F643.

Ebell, M., \& Warren, J. (2016). The long-term economic impact of leaving the EU. National Institute Economic Review, 236, 121-138.

Evenett, S. J. (2016). The ten commandments of an independent UK trade policy. In R. Baldwin (Ed.), Brexit beckons: Thinking ahead by leading economics. London: CEPR.

Gove M. (2016) Britons "have had enough of experts". Sky News interview. https://www.youtube. com/watch?v=GGgiGtJk7MA.

Haldane, A. (2017). Institute for Government speech, January 2017, London. https://www. instituteforgovernment.org.uk/events/andy-haldane-conversation.

HM Government. (2017). The United Kingdom's Exit from and New Partnership with the European Union, CM 9417. London: HMSO https:/www.gov.uk/government/uploads/system/uploads/attachment_ data/file/589191/The_United_Kingdoms_exit_from_and_partnership_with_the_EU_Web.pdf.

HM Treasury (2016a) 'HM Treasury analysis: the long economic impact of EU membership and the alternatives', Cm 9250, London: HM Treasury, https:/www.gov.uk/government/publications/hmtreasury-analysis-the-long-term-economic-impact-of-eu-membership-and-the-alternatives.

HM Treasury (2016b) 'HM Treasury analysis: the immediate economic impact of leaving the EU' Cm 9292, London: HM Treasury, https://www.gov.uk/government/publications/hm-treasury-analysis-theimmediate-economic-impact-of-leaving-the-eu.

Minford, P. (2016) 'The Treasury report on Brexit: A critique' Economists for Brexit, https://static1. squarespace.com/static/58a0b77fe58c624794f29287/t/58a4b012ebbd1a42255bc2f6/1487187989168 /Economists_for_Brexit_The_Treasury_Report_on_Brexit_A_Critique_Executive_Summary.pdf.

Minford, P., \& Miller, E. (2017) 'What shall we do if the EU will not play ball: UK WTO strategy in a noncooperative continent' Economists for Free Trade, https://static1.squarespace.com/static/58a0b77fe58 c624794f29287/t/58f77fa01b631bc0c1e5b307/1492615080915/What-shall-we-do-if-the-EU-will-notplay-ball-110417.pdf.

Minford, P., Gupta, S., Le, V., Mahambare, V., \& Xu, Y. (2016). Should Britain leave the EU? An economic analysis of a troubled relationship (Second ed.). London: Institute of Economic Affairs.

Observatory of Economic Complexity (2017). Visualization tool. http://atlas.media.mit.edu/en/visualize/tree $\mathrm{map} / \mathrm{hs} 92 /$ export/cze/show/all/2015/.

Office of National Statistics (ONS) (2017). Publication tables UK trade, https:/www.ons.gov. uk/economy/nationalaccounts/balanceofpayments/datasets/publicationtablesuktrade.

Petrongolo, B. (2016). Brexit and the UK labour market. In R. Baldwin (Ed.), Brexit beckons: Thinking ahead by leading economics. London: CEPR.

Sampson, T. (2017). 'Four principles for the UK's Brexit trade negotiations' CEP Brexit Analysis no.9, http://cep.lse.ac.uk/brexit/abstract.asp?index $=5242$.

Treasury Committee. (2016). The economic and financial costs and benefits of the UK's EU membership. In First report of session 2016-17, HC 122. London: The House of Commons https://www.publications. parliament.uk/pa/cm201617/cmselect/cmtreasy/122/12204.htmUK.

UK Statistics Authority (2016). UK Statistics Authority Statement on the use of official statistics on contributions to the European Union. https://www.statisticsauthority.gov.uk/news/uk-statistics-authoritystatement-on-the-use-of-official-statistics-on-contributions-to-the-european-union/. 